\title{
THE SECOND TIER: JAPAN'S STAGNATION IN THE FIGHT AGAINST SEX TRAFFICKING
}

\author{
Ellen M. Queen
}

\begin{abstract}
"When you are treated as less than important, you are still a human. When you are treated as less than worthy, you are still a human. When you are treated less than your title, you are still a human. But when you are treated less than the very thing you are born to be, you perish."

-D’Andre Lampkin
\end{abstract}

\section{INTRODUCTION}

\section{A. The Growing Global Black Market and Human Sex Trafficking}

The practice of transnational human trafficking for any purpose, whether sex or labor, is at its heart a byproduct of the global market. With globalization came widespread corruption which, combined with capitalism, led to the growth of illicit markets. ${ }^{1}$ Thus, as globalization continues on its high-speed spread, human trafficking across borders is one of the fastest growing forms of transnational crime. ${ }^{2}$ It follows, then, that as international crime grows, international criminals gain more and more power. "The most striking impact of globalization is the transformation of the power structure among nation-states and non-state authorities - in other words, the decline of sovereign nation states" in favor of other parties such as transnational organized crime syndicates. ${ }^{3}$

There is also, by general extension of vast globalization, a wider global demand market that eager profiteers move to supply. In particular, the illicit market that treats women as goods. Organized criminal groups have participated in the trafficking business "because the capital needed to engage in this business is low, the chance of detection is limited, and one can conduct this business in most regions of the world with few obstacles." ${ }^{4}$ It is particularly problematic that, due to low penalties and high monetary earnings, sex trafficking is, comparatively, a low-risk, high-profit business. ${ }^{5}$

\footnotetext{
${ }^{1}$ Louise Shelly, International Trafficking, Human SECURITY, TRANSNATIONAL CRIME AND Human TrAFFICKING 135, 136-7 (Shiro Okubo \& Louise Shelley eds., Rutledge 2011).

${ }^{2} I d$. at 135

3 Shiro Okubo, Introduction to Human Security, Transnational Crime and Human TrafFicking 1, 12 (Shiro Okubo \& Louise Shelley eds., Rutledge 2011).

${ }^{4}$ Shelly, supra note 1 , at 137.

${ }^{5}$ Iris Yen, Of Vice and Men: A New Approach to Eradicating Sex Trafficking By Reducing Male Demand Though Educational Programs and Abolitionist Legislation, 98 J. CRIM. L. \& Criminology 653, 659 (2008).
} 
Sex trafficking is, frankly, "the perfect criminal business." 6

Human trafficking as a global problem also produces global harm, specifically in the realm of human rights. Harold Hongju Koh, the former Assistant Secretary of State for Democracy, Human Rights, and Labor, expressed this harm before the House Committee on International Relations as:

Traffickers abuse virtually the entire spectrum of rights protected in the Universal Declaration of Human Rights. By their acts, traffickers deny that all persons are born free and equal in dignity and rights; they deny their victims freedom of movement, freedom of association, and the most basic freedom: to have a childhood. Traffickers profit from arbitrary detention, slavery, rape, and cruel, inhuman, and degrading treatment. They regularly violate any human right that gets in the way of a profit. ${ }^{7}$

The complete disregard for the rights of trafficked individuals, in combination with the fast-growing prevalence of those who traffic in human beings, establishes a need for urgent and further reform across the globe. Sex trafficking in particular is a violation beyond forced labor, including the crimes of "rape, torture, and unlawful detention because it is the culmination of all these acts through the deprivation of personal autonomy." 8

It is estimated that, of all human trafficking cases, $79 \%$ were for the purpose of sexual exploitation while $18 \%$ were for forced labor. ${ }^{9}$ Women are "cheap products that can be used and reused." ${ }^{10}$ It is "[t]he mantra in the trafficking industry is that women provide good cheap labor for the slave trade industry because selling a woman is no great loss to society." ${ }^{11}$ It is a cold way to view the effects of sex trafficking, but it is necessary to understand why trafficking has become a global problem.

Japan-with which this Note will deal exclusively-is considered primarily a destination country, but also contributes as a source and transit

\footnotetext{
${ }^{6} I d$. at 658 .

7 The Global Problem of Trafficking in Persons: Breaking the Vicious Cycle on "Trafficking of Women and Children in the International Sex Trade”, Before the House Comm. on Int'l Relations, 106th Cong. 2 (1999) (testimony of Harold Hongju Koh, Assistant Secretary of State).

${ }^{8}$ Alison Cole, Reconceptualizing Female Human Trafficking: The Inhuman Trade in Women, 26 WOMEN's RTS. L. REP. 97, 97 (2005).

9 United Nations Office on Drugs and Crime, Global Report on Trafficking in PERSONS 1, 50 (2009), http://www.unodc.org/documents/human-trafficking/Global_Report _on_TIP.pdf.

${ }^{10}$ Susan W. Tiefenbrun, Symposium, Sex Sells but Drugs Don't Talk: Trafficking of Women Sex Workers and an Economic Solution, 24 T. JEFFERSON L. REv. 161, 175 (2002).

${ }^{11} I d$.
} 
country for human trafficking. ${ }^{12}$ However, organized crime syndicates in Japan (the yakuza), are not wholly responsible, though those groups certainly participate. ${ }^{13}$ In recent years, trafficking perpetrated by smaller scale networks has emerged. ${ }^{14}$ Methods of getting women into the country for the purpose of sexual exploitation range from false promises of legitimate employment to fraudulent marriages to Japanese men. ${ }^{15}$

Japan, in general, has a long history with sex trafficking practices. ${ }^{16}$ However, modern attention was drawn to human trafficking in Japan in the 1980s and early 1990s. ${ }^{17}$ This is because Japan finally became an attractive destination for those who had no special skills or training in the 1980s, causing a boom in foreign workers immigrating to find high-wage jobs. ${ }^{18}$ Currently, Japan is ranked the United States' Trafficking in Persons Report as a Tier 2 nation. ${ }^{19}$ It is the position of this Note that Japan remains on the Tier 2 list because of stagnation of the Japanese government's political will in regards to continuing the fight against human sex trafficking. However, this Note also advocates for changes to Japanese law not necessarily reflected in the United State's requirements to attain Tier 1 status due to the criticisms of the United States system and proposals of more effective methods.

\section{B. Issues}

Part II will discuss Japan's legal and social history in regards to sex trafficking and sexual slavery. Japan's history with human trafficking dates back to its feudal times. There were also indications of sex trafficking by the Japanese military during World War II. Lastly, this section will address human rights and constitutional reforms in Japan post-World War II. Part III of this Note will deal with the United Nations Trafficking in Persons Protocol ("UN TIP Protocol") and discuss the theoretical framework of the Protocol, including various relevant provisions and definitions. Having discussed the Protocol, Part IV will then move on to discuss Japan's general obligations under international law.

Part V will detail the United States' Tier System., a system that

12 U.S. State Department, Trafficking in Persons Report 2013, “Japan,” http://www.state.gov/documents/organization/210740.pdf.

${ }^{13} I d$.

${ }^{14} \mathrm{Id}$.

${ }^{15} \mathrm{Id}$.

${ }^{16}$ See infra Section II.

17 Yuriko Saito, The trafficking of Thai women to Japan and countermeasures of the Thai government, Human SECURity, TRANSNATIONAL CRIME AND Human TRAFFICKING 233, 234 (Shiro Okubo \& Louise Shelley eds., Rutledge 2011).

18 Yasuzo Kitamura, Evolution of Antitrafficking in Person Law and Practice in Japan: A Historical Perspective, 14 TUL. J. INT'L \& COMP. L. 331, 347 (2006).

19 U.S. State Department, Trafficking in Persons Report 2013, “Tier Placement,” http://www.state.gov/j/tip/rls/tiprpt/2013/210548.htm. 
delineates how and by what requirements other nations are ranked. This section will also draw similarities between countries in each of the four Tiers. Part VI will then discuss the general known or theorized flaws in both the United Nations Protocol and the United States' Tier System. This will include discussions of the lack of mandatory victim protections and services, restrictions of liberty, and arbitrary evaluations.

Part VII will focus almost exclusively on why Japan is ranked as a Tier 2 nation by the United States. It will go through all three "P's" outlined in the UN TIP Protocol and the United States Tier approach: Prevention, Prosecution, and Protection. It will then, for each "P", analyze why Japan is lacking what the United States expects. This analysis will cover cultural and social traditions, economic influences, current Japanese legislation, and legal realities when it comes to addressing the trafficking in women for the purpose of sexual exploitation.

Lastly, Part VIII of this Note will outline recommendations to improve Japan's status from Tier 2 to Tier 1, and to improve the country's trafficking law in general. These recommendations will include ratifying the UN TIP Protocol, the formation of a regional coalition in East Asia and other Pacific countries, and domestic legal and social changes in regards to immigration and support services for victims.

\section{CONTEXT: JAPANESE PRACTICES AND LAW BEFORE THE UN TIP PROTOCOL}

\section{A. Before World War II}

In order to fully understand the current international legal situation in Japan regarding human sex trafficking, it is important to explore historical context, which was especially extensive before, during, and after World War II. Japan's history with human trafficking, both domestic and international, dates back to the seventh century, when the lowest class of people-called "Nuhi" — could be bought and sold legally. ${ }^{20}$ Nuhi, if literally translated, is comprised of two Japanese characters: the first meaning "manservant" or "slave" and the second meaning "maidservant." 21 The class, as a whole, was therefore the servant or slave class of people. However, it was illegal in Japan to force an individual to become Nuhi through abduction, carrying a "severe punishment."22

The Nuhi class was dismantled about four hundred years later during

20 Atsushi Kondo, Japanese experience and response in combating trafficking, HUMAN Security, Transnational Crime and Human Trafficking 216 (Shiro Okubo \& Louise Shelley eds., Rutledge 2011).

${ }^{21}$ Denshi Jisho, Kanji Details of nuhi , available at http://jisho.org/kanji/details/ \%Е5\%А5\%B4\%E5\%A9\%A2.

${ }^{22} I d$. 
the Kamakura period (1185-1333), during which the Shogunate maintained an uncodified prohibition on trafficking in persons. ${ }^{23}$ Then, when the Portuguese merchants arrived in Japan in the 1500s, Japanese women were targeted for trafficking - most likely for the purpose of sexual exploitation. In response, Shogun Hideyoshi Toyotomi issued a proclamation banning the trade of Japanese persons to foreigners. ${ }^{24}$ However, this did not affect domestic sexual slavery practices. After the proclamation was issued, there did continue through the Edo period (1603-1867) the practice of keeping poor young Japanese women "in a position of servitude as licensed prostitutes.” 25 It was not until 1872, during the Meiji era, that the first non-class related prohibition on the sale of human beings was proclaimed. ${ }^{26}$ The order was called "Shougi-Kaiho-Rei" or "the Decree of Emancipation of Prostitutes," though the decree did not induce much practical change as prostitution itself was still legal so long as the women consented and were not kept against their will. $^{27}$

However, from as early as 1858 until just before World War II, international trafficking in women from Japan continued. ${ }^{28}$ In an attempt to stop this transnational crime, the government passed in the Penal Code of 1907 a prohibition on trafficking in persons that still exists today. ${ }^{29}$ Further, in 1925, Japan became a party to the 1922 International Convention for the Suppression of the Traffic in Women and Children. ${ }^{30}$ Ratification of the

${ }^{23}$ Kitamura, supra note 18, at 334.

${ }^{24} \mathrm{Id}$.

${ }^{25}$ Id. at 335.

${ }^{26}$ This proclamation was made in response the Maria Luz Incident. The Maria Luz was a Peruvian vessel with an "immigration" contract with China. After a storm, a Chinese coolie (unskilled laborer) escaped the ship and was rescued by a British warship which had happened to be nearby. The coolie told the British that he and 230 other Chinese coolies were being treated like slaves aboard the Maria Luz. The coolie was handed over to the Japanese because he was found in Japanese waters. When the caption of the Maria Luz demanded the return of he coolie, the Japanese government refused on humanitarian grounds. A Japanese special court then ruled that all the coolies were to be removed from the ship. The proclamation was made after the Peruvians commented that a country which allowed prostitution as a form of indentured servitude could hardly have the moral high ground in matters of liberation. Kondo, supra note 20; Kitamura, supra note 18, at 335.

${ }^{27}$ Kitamura, supra note 18, at 338-9.

${ }^{28} \mathrm{Id}$. at 340 .

29 Id. at 341; PENAL CODE OF 1907 Articles 226-229 (Japan) available at http://www.cas.go.jp/jp/seisaku/hourei/data/PC.pdf.

${ }^{30}$ Christopher P. Meade, Note, From Shanghai to Globocourt: An Analysis of the "Comfort Women's” Defeat in Hwang v. Japan, 35 VAND. J. TransNAT’L L. 211, 221 (2002); United NATIONS TREATy COLLECTION, 1922 InTERNATIONAL CONVENTION FOR THE SUPPRESSiON OF THE TRAFFIC In WOMEN AND CHILDREN, available at http://reaties.un.org/Pages/

ViewDetails.aspx?src=TREATY\&mtdsg_no=VII-3\&chapter=7\&lang=en. 
Convention, however, did not apply to various Japanese territories. ${ }^{31}$ Then, Japan also became a party to the 1932 International Labour Organization's Convention \#29 on Forced Labour. ${ }^{32}$ Forced labor was defined in the Convention as "all work or service that is exacted from any person under the menace of any penalty and for which the said person has not offered himself voluntarily."33

\section{B. During World War II: Comfort Women}

Despite becoming a party to the latter conventions, Japan did engage in practices of sex trafficking and sexual slavery during World War II. The Japanese military engaged in the use of "comfort women." Comfort women were the "the thousands of young girls and women who were forced into sexual slavery by the Japanese military from 1931 to 1945 ... [The] euphemism was originally coined by the Japanese (from 'ianfu' for 'comfort')." 34

The comfort women used by Japanese forces during the World War II are generally ignored from analysis of Japan's historical relationship with human sex trafficking. ${ }^{35}$ A great problem in Japan is that some members of parliament, who "rationalized the system of military comfort women,"36 "seem to be tolerat[ing]" human trafficking and prostitution. ${ }^{37}$

The policy that led to the procurement of comfort women for Japanese soldiers began as early as 1931 and was definitely in full use by the year $1938 .^{38}$ The program was accelerated after the defeat of the Chinese at Nanking in 1937—known as the "Rape of Nanking — possibly in part because Japanese soldiers were so mentally and spiritually brutalized by the atrocities they were ordered to commit. ${ }^{39}$ "It was a common belief that soldiers should not die as virgins, and many thought that sex before battle protected soldiers against death." 40 Additionally, it seemed that Japanese military leadership hoped to avoid another even like the Rape of Nanking, concluding that access

31 Those territories were Chosen, Taiwan, the leased territory of Kwangtung, the Japanese portion of Saghalien Island and Japan's mandated territories in the South Seas. UNITED Nations Treaty Collection, 1922 InTERnational Convention, supra note 30.

${ }^{32}$ Meade, supra note 30, at 223.

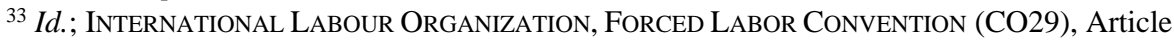

2, available at http://www.ilo.org/dyn/normlex/en/f?p=NORMLEXPUB:12100:0::

NO::P12100_ILO_CODE:C029.

${ }^{34}$ Meade, supra note 30, at ,213 n.1.

${ }^{35}$ E.g., cf., Kitamura, supra note 18, at 338-9.

${ }^{36}$ Hirofumi Hayashi, Disputes in Japan over the Japanese Military “Comfort Women” System and Its Perception in History, 617 ANNALs 123, 130 (2008).

${ }^{37}$ Id.

${ }^{38}$ Meade, supra note 30, at 219.

${ }^{39} \mathrm{Id}$.

${ }^{40} I d$. at 220. 
to comfort women would dissuade Japanese soldiers from raping among the domestic populations of those territories that the Japanese had conquered or otherwise occupied. ${ }^{41}$ It was also theorized that the comfort women program would reduce instances of venereal disease among soldiers and reduce the potential for espionage. ${ }^{42}$

Comfort women were primarily Burmese, Chinese, Dutch, Filipino, Indonesian, Korean, and Taiwanese. ${ }^{43}$ These women were "forcibly and deceptively conscripted" from Japanese colonies-most especially from conquered Korea. ${ }^{44}$ It has been estimated that $80 \%$ of all comfort women were Korean. ${ }^{45}$ There are two reasons put forth as why Japanese women were not more heavily represented in the number of comfort women. First, Japanese women, prostitutes or not, were not plentiful or healthy enough to service soldiers. ${ }^{46}$ Within the realm of this broad reason, other suppositions include reluctance of Japanese women to travel to the front lines, and the decision by the government that Japanese women better served the Japanese Empire by staying home and having children. ${ }^{47}$

The second reason involved Japan intentionally circumventing various international agreements to which it was a party. ${ }^{48}$ By using women of its colonies, Japan hoped to avoid any sanctions it might incur under the 1922 Convention to which it was a party, since Article 14 of the convention allowed nations not to apply the Convention to their colonies. ${ }^{49}$ Also, the use of women from outside its own borders allowed Japan rationalize that its sexual conscription program did not technically violate the International Labor Organization Convention No. 29 on Forced Labor. ${ }^{50}$

\section{After World War II: Occupation and the New Constitution}

After Japan's defeat in World War II, movement again began in the

${ }^{41} I d$. at $219-20$.

${ }^{42} I d$. at 220.

${ }^{43} \mathrm{Id}$.

${ }^{44}$ Meade, supra note 30.

${ }^{45} \mathrm{Id}$.

${ }^{46} I d$. at 220.

${ }^{47}$ Id. at 220.

${ }^{48}$ Reasoning has also been presented that Japan also violated international customary law of the time. There were three other international agreements (the 1904 International Agreement for the Suppression of the "White Slave Traffic", the Convention to Suppress the Slave Trade and Slavery of 1926, and the 1933 International Convention on the Suppression of Traffic in Women of Full Age) to which Japan was not a party but to which other States had agreed. This demonstrates the existence of a custom among international actors concerning forced trafficking of human being which Japan's actions would have violated. See Meade, supra note 30, at 224-5.

${ }^{49}$ Id.; United Nations Treaty Collection, 1922 International Convention, supra note 30.

${ }^{50}$ Meade, supra note 30, at 223. 
direction of fighting against human sex trafficking. The occupation government, called the General Headquarters of the Supreme Commander of the Allied Powers, criminalized prostitution in 1946, which coincided with the beginning of universal Japanese suffrage. ${ }^{51}$ A year later, in response opposition by both owners in the sex industry and "the soldiers of the occupation forces," prostitution was licensed for privately owned establishments in a designated district for "Special Restaurants." 52

This was somewhat ironic since this was the same year in which human rights concepts were introduced in the Constitution of $1947 . .^{53}$ The concepts in the new constitution are credited with helping the Japanese to eliminate the practice of servitude. ${ }^{54}$ In 1950, these newly enumerated human rights concepts were extended by the Japanese Supreme Court: "[I]t should be recognized that any person who stays in Japan is entitled to human rights which he or she should naturally have as a human being even if his or her entry into the country was illegal." 55

Then, in 1955, the Japanese Supreme Court ruled that "a loan repayment request based on a prostitution advance contract was not permitted because it went against the public order and good morals in article 90 of the Civil Code." 56 This ended the legalization of human trafficking in the form of an indentured servitude contract. ${ }^{57}$ Finally, in 1956, as part of the United Nations Convention for the Suppression of the Traffic in Person and of the Exploitation of the Prostitution of Others, the Japanese Diet passed the law on the Prevention of Prostitution that ended all licensing of prostitution in Japan. ${ }^{58}$ This Note suggests that the illegalization of prostitution in this context should be taken to indicate an effort to end sexual exploitation, not necessarily consensual sex work.

\section{THE UN TIP PROTOCOL}

\section{A. A Law Enforcement Framework}

The United Nations Trafficking in Persons Protocol is based upon a

${ }^{51}$ Kitamura, supra note 18 , at 341.

52 Id.; see also ILO CONVENTION No. 29 CONCERNING ForCED OR COMPUlSORY LABOR, 39 U.N.T.S. 55, art. 2 (1930).

53 THE CONSTITUTION OF JAPAN (1947), available at http://history.hanover.edu/texts/1947con .html.

${ }^{54}$ Kitamura, supra note 18, at 342.

55 Kerry E. Yun, How Japan's Recent Efforts to Reduce Sex Trafficking Can be Improved Through International Human Rights Enforcement Mechanisms: Fulfilling Japan's Global Legal Obligations, 13 Buff. HuM. RTs. L. REV., 205, 215 (2007).

${ }^{56}$ Kitamura, supra note 18, at 342.

${ }^{57} \mathrm{Id}$.

${ }^{58}$ Id. at 343. 
Law Enforcement model of human trafficking prohibition laws. ${ }^{59}$ This is in evidence by the fact that the Protocol focuses mainly on criminalizing various forms of trafficking and punishing traffickers. ${ }^{60}$ The Protocol was drafted as an addendum to the United Nations Convention on Transnational Organized Crime, which obligates States to accede or ratify the Convention in order to become a Party to the Protocol. ${ }^{61}$ The Protocol focuses, as mentioned above, on mandating the criminalization of conduct and punishment of traffickers, and leaves support for victims as merely optional. ${ }^{62}$

There are advantages to this model. ${ }^{63}$ As a law enforcement treaty, the Protocol possessed far more "influence" than more "inspirational" instruments. ${ }^{64}$ A State that becomes party to the Protocol "has an obligation to create legislation that supports these provisions at the domestic level." 65 Therefore, the United Nations Protocol to Prevent, Suppress, and Punish Trafficking in Persons, Especially Women and Children, allows for direct prosecution of transnational human traffickers and allows individuals to be held accountable for their criminal actions. ${ }^{66}$ In order to accomplish the goal of prosecution, then, resources must be allocated specifically to the fight against trafficking. ${ }^{67}$ Also, law enforcement oriented approaches tend to draw the public eye due to government and police efforts. ${ }^{68}$ This approach addresses a need of "a coordinated law enforcement response" 69 to trafficking and all other related offenses.

\section{B. The Protocol: Definitions and Requirements}

The UN Protocol is generally considered a "milestone"70 in the fight against international trafficking in persons because it is the first time the issue was addressed by an international body. ${ }^{71}$ It has three main parts: criminal

59 Elizabeth M. Bruch, Models Wanted: The Search for An Effective Response to Human Trafficking, 40 STAN. J. INT'L L. 1, 16 (2004).

${ }^{60}$ See generally United NATIONS Protocol to PREVEnt, SuPPRESS AND PUNISH TRAFFicking in Persons, EsPecially Women AND ChildRen, http://www.uncjin.org/

Documents/Conventions/dcatoc/final_documents_2/convention_\%20traff_eng.pdf.

${ }^{61}$ Bruch, supra note 59.

${ }^{62} \mathrm{Id}$. at $16-7$.

63 There are also, however, disadvantages. See infra Section III(C).

${ }^{64}$ Lindsay King, Topical Research Digest: Human Rights and Human Trafficking, "International Law and Human Trafficking," http://www.du.edu/korbel/hrhw/researchdigest/ trafficking/InternationalLaw.pdf.

${ }^{65}$ Id.

${ }^{66}$ Bruch, supra note 59, at 17.

${ }^{67}$ Id.

${ }^{68} \mathrm{Id}$.

${ }^{69} \mathrm{Id}$.

${ }^{70}$ Yen, supra note 4, at 661.

${ }^{71}$ Id.; see also King, supra note 64. 
sanctions, protection of victims, and prevention. ${ }^{72}$ The Protocol begins requirements for criminal sanctions by defining "trafficking in persons" as:

the recruitment, transportation, transfer, harbouring or receipt of persons, by means of the threat or use of force or other forms of coercion, of abduction, of fraud, of deception, of the abuse of power or of a position of vulnerability or of the giving or receiving of payments or benefits to achieve the consent of a person having control over another person, for the purpose of exploitation. ${ }^{73}$

Article 3 continues on to name examples of "exploitation," listing as automatically included activities such as sexual exploitation, the removal of organs, and slavery. ${ }^{74}$ This definition is made even more compelling when, in the same article, the Protocol states that the definition is to be applied regardless of whether or not the trafficked person(s) consented to any activities. $^{75}$

Definitions established, the Protocol moves on to the area of criminal sanctions, outlining the general obligations of party States. Article 5 states that each party "shall adopt such legislative and other measures as may be necessary to establish as criminal offences the conduct set forth in article 3 of this Protocol, when committed intentionally."76 Those criminal offenses shall include acting as an accomplice, attempting, or organizing others to commit any of the acts listed in Article $3 .^{77}$

The second section of the Protocol addresses the protection of victims, mandating that all States, when possible, "shall protect the privacy and identity of victims of trafficking in persons" ${ }^{78}$ and shall provide victims with

\footnotetext{
72 United Nations Protocol to Prevent, Suppress and Punish Trafficking in Persons, ESPECIALlY WOMEN AND CHILDREN, http://www.uncjin.org/Documents/Conventions/dcatoc/ final_documents_2/convention_\%20traff_eng.pdf.

73 United Nations Protocol to Prevent, Suppress and Punish Trafficking in Persons, ESPECIALly WOMEN AND CHILDREN, article 3(a), http://www.uncjin.org/Documents/ Conventions/dcatoc/final_documents_2/convention_\%20traff_eng.pdf.

${ }^{74}$ Id.

75 United Nations Protocol to Prevent, Suppress and Punish Trafficking in Persons, ESPECIALLY WOMEN AND CHILDREN, article 3(b), http://www.uncjin.org/Documents/ Conventions/dcatoc/final_documents_2/convention_\%20traff_eng.pdf.

${ }^{76}$ United Nations Protocol to Prevent, Suppress and Punish Trafficking in Persons, ESPECIALLY WOMEN AND CHILDREN, article 5(1), http://www.uncjin.org/Documents/ Conventions/dcatoc/final_documents_2/convention_\%20traff_eng.pdf.

77 United Nations Protocol to Prevent, Suppress and Punish Trafficking in Persons, EsPECIALly WOMEn AND CHILDREN, article 5, http://www.uncjin.org/Documents/ Conventions/dcatoc/final_documents_2/convention_\%20traff_eng.pdf.

${ }^{78}$ United Nations Protocol to Prevent, Suppress and Punish Trafficking in Persons, ESPECIALlY WOMEN AND CHILDREN, article 6(1), http://www.uncjin.org/Documents/ Conventions/dcatoc/final_documents_2/convention_\%20traff_eng.pdf.
} 
all relevant information pertaining to legal and administrative processes. ${ }^{79}$ The Protocol requires that all State Parties shall institute programs and services to care for the "physical, psychological, and social recovery" of victims. ${ }^{80}$ Such programs and services should include, for example, appropriate housing, ${ }^{81}$ medical and material assistance, ${ }^{82}$ and employment opportunities. ${ }^{83}$ Additionally, for appropriate cases, a State shall "consider adopting legislative or other appropriate measures that permit victims of trafficking in persons to remain in its territory. ..." 84

Article 9 begins the next set of obligations for States: prevention. Article 9 generally outlines that States Parties to the Protocol shall undertake various measures in order to both prevent human trafficking and also to protect victims from re-victimization. ${ }^{85}$ States are responsible for enacting preventative measures in the areas of research and information, media campaigns, and social and economic initiatives. ${ }^{86}$ The Protocol also calls for more stringent immigration policies, including the examination of identification documents used by immigrants. ${ }^{87}$ The Protocol also, importantly, encourages States to tackle the issue of demand markets that "foster sexual exploitation." ${ }^{88}$

79 United Nations Protocol to Prevent, Suppress and Punish Trafficking in Persons, ESPECIALLY WOMEN AND CHILDREN, article 6(2), http://www.uncjin.org/Documents/ Conventions/dcatoc/final_documents_2/convention_\%20traff_eng.pdf.

${ }^{80}$ United Nations Protocol to Prevent, Suppress and Punish Trafficking in Persons, ESPECIALLY WOMEN AND CHILDREN, article 6(3), http://www.uncjin.org/Documents/ Conventions/dcatoc/final_documents_2/convention_\%20traff_eng.pdf.

81 United Nations Protocol to Prevent, Suppress and Punish Trafficking in Persons, ESPECIALLY WOMEN AND CHILDREN, article 6(3)(a), http://www.uncjin.org/Documents/ Conventions/dcatoc/final_documents_2/convention_\%20traff_eng.pdf.

82 United Nations Protocol to Prevent, Suppress and Punish Trafficking in Persons, ESPECIALLY WOMEN AND CHILDREN, article 6(3)(c), http://www.uncjin.org/Documents/ Conventions/dcatoc/final_documents_2/convention_\%20traff_eng.pdf.

83 United Nations Protocol to Prevent, Suppress and Punish Trafficking in Persons, ESPECIALLY WOMEN AND CHILDREN, article 6(3)(d), http://www.uncjin.org/Documents/ Conventions/dcatoc/final_documents_2/convention_\%20traff_eng.pdf.

${ }^{84}$ United Nations Protocol to Prevent, Suppress and Punish Trafficking in Persons, ESPECIALLY WOMEN AND CHILDREN, article 7, http://www.uncjin.org/Documents/ Conventions/dcatoc/final_documents_2/convention_\%20traff_eng.pdf.

${ }^{85}$ United Nations Protocol to Prevent, Suppress and Punish Trafficking in Persons, ESPECIALLY WOMEN AND CHILDREN, article 9, http://www.uncjin.org/Documents/ Conventions/dcatoc/final_documents_2/convention_\%20traff_eng.pdf.

86 United Nations Protocol to Prevent, Suppress and Punish Trafficking in Persons, ESPECIALLY WOMEN AND CHILDREN, article 9(2), http://www.uncjin.org/Documents/ Conventions/dcatoc/final_documents_2/convention_\%20traff_eng.pdf.

${ }^{87}$ United Nations Protocol to PreVent, Suppress AND PUNISH TrafFicking In PERSONS, ESPECIALLY WOMEN AND CHILDREN, articles 11 \& 12, http://www.uncjin.org/Documents/ Conventions/dcatoc/final_documents_2/convention_\%20traff_eng.pdf.

${ }^{88}$ Yen, supra note 4, at 661 . 


\section{POST-UN PROTOCOL JAPAN (2002-2009)}

\section{A. Japan's Obligations Under the United Nations Trafficking in Persons Protocol}

Unfortunately, Japan's obligations under the UN Trafficking in Persons Protocol are meager, at best, since the Diet has not, as of yet, become a party to it. ${ }^{89}$ Having signed the Protocol, Japan only has an obligation not to defeat the object and purpose of the Protocol. ${ }^{90}$ Though, because of the international cooperation considered necessary to combat human sex trafficking, ${ }^{91}$ Japan's perceived lack of action concerning sex trafficking could certainly be considered as defeating the object and purpose of the UN TIP Protocol.

However, Japan has made recent attempts to conform to the Protocol despite not being formally bound by it, having published two governmental action plans that attempt to pull Japanese laws and practices in line with the Protocol. ${ }^{92}$ Of course, rather than the Protocol, Japan could be responding more towards evaluations made by the United States Trafficking in Persons Report.

Even in the absence of any obligation imposed by the Protocol, Japan is still bound by the principles enumerated in the Universal Declaration of Human Rights, which have risen to the level of customary international law. ${ }^{93}$ The Declaration, through a combination of various universal rights, prohibits human sex trafficking. These rights include a person's right to life, liberty, and security of person; $;^{94}$ to be free from slavery and the slave trade; ${ }^{95}$ and to be free from cruel, inhuman, or degrading treatment. ${ }^{96}$ These human rights are also contained within Japan's Constitution, making this international

\footnotetext{
${ }^{89}$ It should be noted that Japan is a party to several other international agreements that can be tangentially applied towards Japan's international obligations to address human trafficking. For a summary of these treaties, see Yun, supra note 55, at 235-7. However, this Note deals specifically with the UN Trafficking in Persons Protocol and the US Tier System.

90 Vienna Convention on the LAW of Treaties (1969), article 18, http://legal.un.org/ilc/texts/instruments/english/conventions/1_1_1969.pdf.

91 Tahseen Hasan Mutlag, Erin Kulpa, Jennifer Stark, Zorica Travar \& Evelyn Yiyang Wu, NAAGAZETTE, "Best Practices in Human Trafficking Law" (2012), available at http://www.naag.org/best-practices-in-human-trafficking-law.php.

92 See e.g., Ministerial Meeting Concerning Measures Against Crimes in Japan, JAPAN’s 2009 ACtion Plan to COMBAt TrafFicking IN PERSOns, http://www.mofa.go.jp/ j_info/visit/visa/topics/pdfs/actionplan0912.pdf.

${ }^{93}$ King, supra note 64.

${ }^{94}$ Universal DeClaration of Human Rights (1948), article 3, http://www.un.org/en/ documents/udhr/.

95 Universal DeClaration of Human Rights (1948), article 4, http://www.un.org/en/ documents/udhr/.

96 Universal Declaration of Human Rights (1948), article 5, http://www.un.org/en/ documents/udhr/.
} 
obligation also a domestic one. ${ }^{97}$ Additionally, Japan has exhibited signs of seeking approval from the United States in regards to laws concerning human sex trafficking. ${ }^{98}$ This seeking of approval shows a perceived obligation from Japan to comply with international standards propagated by the United States and U.S. domestic laws.

\section{B. Japan's Subsequent Legal Reforms in the Post-Protocol Era}

The Diet began an examination of reforming the laws after signing the Protocol in 2002. ${ }^{99}$ However, the Japanese government obviously did not get very far in such reforms, because, in 2004, Japan was put on the Tier 2 Watch List by the U.S. State Department. ${ }^{100}$ "Embarrassed" by such "direct criticism", the government established a task force to combat trafficking in Japan. ${ }^{101}$ Thus, a national plan of action was composed and put into effect immediately. The Comprehensive Action Plan included measures to increase enforcement of "immigration controls, assurance of the security of travelrelated documents, review of status of residence and visas for 'entertainers,' countermeasures against false marriages, measures to prevent illegal employment, and measures to prevent prostitution." 102

In 2005, revisions were made to the Penal Code, and to Immigration Laws to include the UN Protocol. ${ }^{103}$ The crime of "buying and selling of persons, as well as transporting, transferring, and harboring victims of kidnapping, abduction, buying and selling” was added to the Penal Code. ${ }^{104}$ The punishment for this crime is imprisonment for no less than three months and no more than five years, enhanced to seven years if the victim is a minor. ${ }^{105}$ Immigrations laws were changed to give victims of trafficking special status that they did not possess before, which would protect them from punitive fines, jail time, and deportation. ${ }^{106}$ They are eligible for some social services. ${ }^{107}$ It was made a crime to procure, provide or possess a fraudulent foreign passport for the purpose of facilitating illegal entry into

\footnotetext{
${ }^{97}$ Yun, supra note 55, at 235.

${ }^{98}$ Kitamura, supra note 18, at 348-49 (2006).

${ }^{99}$ Kondo, supra note 20, at 218.

${ }^{100} \mathrm{Id}$.

${ }^{101}$ Kitamura, supra note 18, at 348-49 (2006).

102 Id. at 349.

${ }^{103} \mathrm{Id}$. at 349.

${ }^{104}$ Id. at 343 (2006); PENAL CODE OF 1907 Articles 226-229 (Japan), http://www.cas.go.jp /jp/seisaku/hourei/data/PC.pdf.

105 Kitamura, supra note 18, at 343; PENAL CoDE OF 1907 Articles 226-229 (Japan) available at http://www.cas.go.jp/jp/seisaku/hourei/data/PC.pdf.

${ }^{106}$ Kitamura, supra note 18, at 343.; PENAL CODE OF 1907 Articles 226-229 (Japan) available at http://www.cas.go.jp/jp/seisaku/hourei/data/PC.pdf.

${ }^{107}$ Kitamura, supra note 18, at 343.; PENAL CODE OF 1907 Articles 226-229 (Japan) available at http://www.cas.go.jp/jp/seisaku/hourei/data/PC.pdf.
} 
Japan. $^{108}$

Japan made further efforts to reform its laws in 2009, publishing another Action Plan. ${ }^{109}$ This plan acknowledges that, as of 2009, Japanese laws and victim support practices regarding human trafficking were insufficient and essentially promises more aggressive policing, more focused efforts as detection of victims, and general expansion of victim services. ${ }^{110}$ In general, only the efforts at victim identification seem to have been successful. ${ }^{111}$

\section{EXAMINATION OF THE UNITED STATES TIER SYSTEM}

\section{A. Minimum Requirements and Criteria of Evaluation}

The same year that the UN TIP Protocol was adopted, the United States legislature passed The Victims of Trafficking and Violence Protection Act of 2000. ${ }^{112}$ The Act addressed the problem of human trafficking in the same three-pronged manner of the UN Protocol: prevention, prosecution (or criminal sanctions), and protection of victims. ${ }^{113}$ Part of this Act required a yearly report be published by the U.S. State Department on the status of foreign powers' current human and sex trafficking efforts. ${ }^{114}$ The Act established a minimum, broad standard that foreign countries are evaluated by:

For purposes of this chapter, the minimum standards for the elimination of trafficking applicable to the government of a country of origin, transit, or destination for victims of severe forms of trafficking are the following:

(1) The government of the country should prohibit severe

108 Kitamura, supra note 18, at 350.

109 Ministerial Meeting Concerning Measures Against Crimes in Japan, Japan’s 2009 Action Plan to COMBAt TrafFicking in Persons, available at http://www.mofa.go.jp /j_info/visit/visa/topics/pdfs/actionplan0912.pdf.

${ }^{110} I d$.

111 In 2010, a total of 43 victims were reported, compared to 17 in 2009. Then, in 2011, 45 victims were reported. United NATIONs OfFice of Drugs AND CRIME, Country PRofiLes: SOUTH ASIA, EAST ASIA AND THE PACIFIC, “Japan” (2012), available at http://www.unodc.org/documents/data-and-analysis/glotip/Country_Profiles_South_Asia_ East_Asia_and_Pacific.pdf.

112 The Victims of Trafficking and Violence Protection Act of 2000, Div. A of Pub. L. No. 106-386, available at http://www.state.gov/j/tip/laws/61124.htm.

113 Yen, supra note 5, at 663; The Victims of TrAfFicking AND ViOLENCE Protection ACT OF 2000, Div. A of Pub. L. No. 106-386, $t$ http://www.state.gov/j/tip/laws/61124.htm.

114 The Victims of Trafficking and Violence Protection Act of 2000, Div. A of Pub. L. No. 106-386, §104, $t$ http://www.state.gov/j/tip/laws/61124.htm. 
forms of trafficking in persons and punish acts of such trafficking.

(2) For the knowing commission of any act of sex trafficking involving force, fraud, coercion, or in which the victim of sex trafficking is a child incapable of giving meaningful consent, or of trafficking which includes rape or kidnapping or which causes a death, the government of the country should prescribe punishment commensurate with that for grave crimes, such as forcible sexual assault.

(3) For the knowing commission of any act of a severe form of trafficking in persons, the government of the country should prescribe punishment that is sufficiently stringent to deter and that adequately reflects the heinous nature of the offense.

(4) The government of the country should make serious and sustained efforts to eliminate severe forms of trafficking in persons. ${ }^{115}$

The Act provides further clarification on subsection 4 on what qualifies as making serious and sustained efforts. First, the country must "vigorously" investigate and prosecute all persons engaged in the trafficking of human beings. ${ }^{116}$ Second, the state must protect victims of trafficking, providing alternatives to deportation and criminal penalties. ${ }^{117}$ The third criterion asks whether the country has provided information and education about human trafficking to the population and in particular to potential victims. ${ }^{118}$ Fourth, the state must cooperate with other states in the realm of investigating and preventing human trafficking crimes. ${ }^{119}$ The other criteria include whether the country extradites persons charged with trafficking crimes, ${ }^{120}$ whether the country observantly monitors immigration patterns for evidence of

115 The Victims of Trafficking And Violence Protection Act of 2000, Div. A of Pub. L. No. 106-386, § 108(a), $t$ http://www.state.gov/j/tip/laws/61124.htm,

116 The Victims of Trafficking and Violence Protection Act of 2000, Div. A of Pub. L. No. 106-386, § 108(b)(1), available at http://www.state.gov/j/tip/laws/61124.htm, 117 The Victims of Trafficking and Violence Protection Act of 2000, Div. A of Pub. L. No. 106-386, § 108(b)(2), available at http://www.state.gov/j/tip/laws/61124.htm,

118 The Victims of Trafficking and Violence Protection Act of 2000, Div. A of Pub. L. No. 106-386, § 108(b)(3), available at http://www.state.gov/j/tip/laws/61124.htm, 119 The Victims of Trafficking and Violence Protection Act of 2000, Div. A of Pub. L. No. 106-386, § 108(b)(4), available at http://www.state.gov/j/tip/laws/61124.htm, 120 The Victims of Trafficking and Violence Protection Act of 2000, Div. A of Pub. L. No. 106-386, § 108(b)(5), available at http://www.state.gov/j/tip/laws/61124.htm, 
trafficking, ${ }^{121}$ and whether the country "vigorously investigates and prosecutes" public officials found to be involved in human trafficking. ${ }^{122}$

\section{B. Tier Requirements}

The U.S. Tier Ranking System is divided into four categories: Tier 3, Tier 2 Watch List, Tier 2, and Tier 1. Tier 3 is considered the worst, while Tier 1 is considered the best. ${ }^{123}$

Tier 3 encompasses those countries "whose governments do not fully comply with the minimum standards and are not making significant efforts to do so." ${ }^{124}$ This category seems to be primarily composed of Muslim or Middle Eastern/African countries. ${ }^{125}$ For example, Saudi Arabia, Congo, Algeria, Iran, Kuwait, Libya, Mauritania, and Uzbekistan are all on the Tier 3 list. ${ }^{126}$ However, China, Russia, Paraguay and others are also considered to have sub-standard human trafficking prevention practices. ${ }^{127}$ Any nation included on Tier 3 may face diplomatic consequences from the United States, including but not limited to the withholding of non-humanitarian, non-traderelated foreign assistance. ${ }^{128}$ There is also the possibility of general financial sanctions. $^{129}$

The Tier 2 Watch List has a much more complex set of criteria than Tier 3. Countries on the Watch List do not fully comply with the United States' Trafficking Victims Protection Act but are making "significant efforts" 130 in order to establish the minimum required standards and

a) The absolute number of victims of severe forms of trafficking is very significant or is significantly increasing;

b) There is a failure to provide evidence of increasing efforts to combat severe forms of trafficking in persons from

\footnotetext{
121 The Victims of Trafficking and Violence Protection Act of 2000, Div. A of Pub. L. No. 106-386, § 108(b)(6), available at http://www.state.gov/j/tip/laws/61124.htm,

122 The Victims of Trafficking and Violence Protection Act of 2000, Div. A of Pub. L. No. 106-386, § 108(b)(7), available at http://www.state.gov/j/tip/laws/61124.htm,

123 U.S. State Department, Trafficking in Persons Report 2013, “Tier Placement”, available at http://www.state.gov/j/tip/rls/tiprpt/2013/210548.htm.

${ }^{124} \mathrm{Id}$.

${ }^{125} \mathrm{Id}$

${ }^{126} I d$.

${ }^{127} I d$.

128 U.S. State Department, Trafficking in Persons Report 2013, 47, http://www.state.gov/documents/organization/210737.pdf.

${ }^{129}$ Amanda Peters, Disparate Protections for American Human Trafficking Victims, 61 CLEV. ST. L. REV. 1, 7 (2013).

130 U.S. State Department, Trafficking in Persons Report 2013, “Tier Placement,” http://www.state.gov/j/tip/rls/tiprpt/2013/210548.htm.
} 
the previous year; or

c) The determination that a country is making significant efforts to bring itself into compliance with minimum standards was based on commitments by the country to take additional future steps over the next year. ${ }^{131}$

There are a variety of countries on this list. Afghanistan, Barbados, Cambodia, Haiti, Rwanda, and Sri Lanka all are on the Watch List. Japan was on this list in 2004, but after its initial efforts was moved off this list the next year to the Tier 2 group. ${ }^{132}$

Tier 2 countries also are not found to comply with U.S. minimum standards, but are at least "making significant efforts to bring themselves into compliance with those standards." "133 This is where the majority of countries, Japan included, are currently placed. ${ }^{134}$

The coveted rank of Tier 1 means that all nations in this group fully comply with U.S. minimum standards. ${ }^{135}$ Members include Canada, the United States, Sweden, and Germany. ${ }^{136}$

\section{FLAWS OF THE UN PROTOCOL AND THE TIER SYSTEM}

\section{A. Criticisms, Gaps, and Issues}

In order to evaluate the United States' Tier System, it is necessary to evaluate whether or not the UN Protocol is actually effective. The Tier System, for all that is an American instrument, borrows heavily from the UN Protocol requirements. This evaluation is necessary in order to make judgments on Japanese laws and recommendations for improvement.

There have been flaws pointed out in the Protocol. For example, the suggestion of decreasing demand for trafficked persons as a method of prevention is "weak and unenforceable." ${ }^{137}$ As a corollary, then, the U.S. federal human trafficking laws have similarly ignored the existence of demand markets, ${ }^{138}$ and generally do not use reduction of demand as a criterion for evaluation. ${ }^{139}$ The only exception to that exists in the in relation

\footnotetext{
${ }^{131} \mathrm{Id}$.

${ }^{132} \mathrm{Id}$.

${ }^{133} \mathrm{Id}$.

${ }^{134} \mathrm{Id}$.

${ }^{135} \mathrm{Id}$.

${ }^{136} I d$.

${ }^{137}$ Yen, supra note 4, at 662.

${ }^{138} \mathrm{Id}$. at 662, 664.

139 See infra Section V(A). However, in the 2005 Reauthorization of the TVPA, a provision was added which funded domestic programs directed at reducing demand, though much more still needs to be done. Yen, supra note 4, at 665.
} 
to decreasing demand is in Victims of Trafficking and Violence Protection Act, which called for efforts to decrease demand for commercial sex acts and participation in sex tourism by nationals of the country. ${ }^{140}$ However, there is a significant difference between purchasing the time of a prostitute-a commercial sex act-and making use of or paying for an imported sex slave-a by-product of human sex trafficking.

Another proposed flaw, in the same vein, is that the United States' Victim of Trafficking and Violence Protection Act, with its definition of trafficking lacking a consent factor, is that it promotes the abolitionist approach to prostitution. The abolitionist approach advocates for the total illegalization of sex work. ${ }^{141}$ It has been previously suggested that abolishment of legitimate sex work actually increases instances of sex trafficking by "forcing women to be dependent on third parties for protection from the law, rendering them vulnerable to exploitation." ${ }^{142}$ The United Nations Protocol does not suffer from this particular drawback, the issue of consent being rendered irrelevant once the victim begins to suffer from exploitation. ${ }^{143}$

Additionally, the Protocol lacks protections for victims of trafficking. ${ }^{144}$ The Protocol does not mandate Member States, for example, to implement victim support programs such as housing, employment, and counseling. ${ }^{145}$ While the United States Tier System uses victim services as one factor in determining a country's status, there are no specific requirements for which programs and services ought to be made available to those who are victims of trafficking. ${ }^{146}$ Instead, like the UN Protocol, the United States requires only that other countries criminalize trafficking and its related offense, punish traffickers, and attempt to eliminate all forms of modern-day slavery in order for other countries to avoid sanctions. ${ }^{147}$

\footnotetext{
140 The Victims of Trafficking and Violence Protection Act of 2000, Div. A of Pub. L. No. 106-386, § 108(b)(11), available at http://www.state.gov/j/tip/laws/61124.htm; as amended available at http://www.state.gov/j/tip/rls/tiprpt/2013/210553.htm.

${ }^{141}$ Cole, supra note 8 , at 98-9.

142 Id. at 111; see also Global Alliance Against Traffic in Women, Moving Beyond 'Supply and Demand' Catchphrases: Assessing the Uses and Limitations of Demand-Based Approaches in Anti-Trafficking 24-42 (2011), http://www.gaatw.org/publications/ MovingBeyond_SupplyandDemand_GAATW2011.pdf.

143 Bruch, supra note 59, at 20.

144 Tal Raviv, Symposium, International Trafficking in Persons: A Focus on Women and Children-The Current Situation and the Recent International Legal Response, 9 CARDOZO WomEN's L.J. 659, 668 (2003); Bruch, supra note 59, at 21.

145 See United Nations Protocol to Prevent, Suppress and Punish Trafficking in Persons, EsPeCially Women AND CHILDREN, article 6, http://www.uncjin.org/Documents/ Conventions/dcatoc/final_documents_2/convention_\%20traff_eng.pdf; see also Raviv, supra note 137.

146 U.S. State Department, Trafficking in Persons Report 2013, “Tier Placement”, available at http://www.state.gov/j/tip/rls/tiprpt/2013/210548.htm.

${ }^{147}$ Peters, supra note 128 , at 5.
} 
Another criticism of the U.N. Protocol (and of all international law dealing with sex trafficking) is that the Protocol leaves too much up to individual States. ${ }^{148}$ This includes immigration frameworks and laws regarding prostitution. ${ }^{149}$ This non-uniformity among domestic laws worldwide "will continue to inhibit attempts to combat female trafficking, due to the capacity of organized crime to exploit the comparative disparity in state legal systems." 150

The Protocol, as a byproduct of being a law enforcement oriented effort, marginalizes human rights concerns, ${ }^{151}$ which is surprising given the gross violations of human rights produced by human sex trafficking. In fact, the Protocol itself has the potential to produce its own human rights concerns because the law enforcement approach advocated by the Protocol could unreasonably restrict the liberty of movement and the right to privacy of migrants. ${ }^{152}$

However, despite these various (and important) drawbacks, the United Nations Protocol and domestic laws which stem from the Protocol are thought to be a step in the right direction when it comes to human trafficking. ${ }^{153}$ In particular, such instruments create obligations and standards that attempt to encourage improvement beyond the status quo of the realities of the sex trafficking industry. ${ }^{154}$

\section{B. Is the Tier System Effective?}

Of course it is necessary to address the accuracy and effectiveness of the United States' Tier Ranking System before analysis of Japanese law and practices can occur. There is, first, a criticism of the United States assuming the position of the moral or legal enforcer to bully other nations into conforming to U.S. practices. ${ }^{155}$ Another problem pointed out by critics is the United States took ten years to begin including its own efforts and laws in the Tier System and in the Trafficking in Persons Report issued by the Department of State. ${ }^{156}$ This lends some credence to the supposition that perhaps it took the United States 10 years to comply with its own Tier 1 requirements.

There is also the appearance of bias or, at the least, odd evaluations of foreign countries. South Korea is an excellent example within the East Asian

\footnotetext{
${ }^{148}$ Cole, supra note 8 , at 111.

${ }^{149} \mathrm{Id}$.

${ }^{150} I d$.

${ }^{151}$ Bruch, supra note 59, at 21

${ }^{152}$ Id.

153 King, supra note 64.

${ }^{154} \mathrm{Id}$.

155 Peters, supra note 128 , at 9.

${ }^{156}$ Id.
} 
region. In 2001, the first TIP Report issued by the United States' Department of State listed South Korea as a Tier 3 country. ${ }^{157}$ At the time, South Korea did lack a formal trafficking law and did have a well-established sex trafficking industry. ${ }^{158}$ However, one year later, South Korea was elevated to Tier 1 status, completely without merit for the extreme promotion. ${ }^{159}$ When the United States granted South Korea this new designation, South Korea did not have an actual trafficking law. ${ }^{160}$ In the year between the 2001 and 2002 reports, South Korea had made efforts to achieve compliance with United States standard, but in 2002 still had failed to meet the minimum stated requirements for Tier 1 status. ${ }^{161}$

In 2005, the Trafficking in Persons Report named South Korea as having the best international practices in combating trafficking, still without South Korea passing a comprehensive anti-trafficking law. ${ }^{162}$ As of 2011, South Korea had still not passed such a law and continued to be awarded Tier 1 status year after year. ${ }^{163}$ This odd evaluation in the case of South Korea indicates either arbitrary evaluations or some form of bias involved in the Trafficking in Persons Report's Tier System. ${ }^{164}$

However, the Tier System is generally thought of as being effective in that it encourages — perhaps pressures ${ }^{165}$ — other nations, even those who are not members of the United Nations Protocol, to adopt practices which attempt to curtail sex trafficking. ${ }^{166}$ In general, the Trafficking in Persons Reports have described most nations as making attempts to tackle the human sex trafficking (and other forms of trafficking) problem. ${ }^{167}$

Specifically, sub-par rankings, such as Tier 3 or the Tier 2 Watch List, can embarrass some nations into making changes in their domestic laws. For example, "the TIP Report succeeded because it embarrassed South Korea by ranking it a Tier 3 country and pressured it to change its policies to avoid

\footnotetext{
157 U.S. State Department, Trafficking in Persons Report 2001, “Country NarrativesTier 3”, http://www.state.gov/documents/organization/4107.pdf.

158 See generally Ayla Weiss, Note, Ten Years of Fighting Trafficking: Critiquing the Trafficking in Persons Report Through the Case of South Korea, 13 AsIAN-PACIFIC L. \& POL'Y J. 304 (2012).

${ }^{159} \mathrm{Id}$. at 327.

${ }^{160} \mathrm{Id}$. at 327.

${ }^{161} \mathrm{Id}$. at 327.

162 Id. at 327.

163 Id. at 327.

${ }^{164}$ Working around such issues will be addressed in the recommendation section. See infra Part VII.

165 Mindy M. Willman, Note, Human Trafficking in Asia: Increased Individual and State Accountability Through Expanded Victims’ Rights, 22 ColuM. J. AsIAN L. 283, 288-9 (2009). 166 “The TVPA has numerous strengths: its broad definition of trafficking, its creation of a baseline measure of trafficking internationally, and its ability to persuade foreign countries to create better anti-trafficking laws and policies ." (emphasis added). Weiss, supra note 165, at 313.

${ }^{167}$ Willman, supra note 165, at 290.
} 
future political repercussions.” ${ }^{168}$ Also, Japan itself, as mentioned earlier, was affected by such embarrassment when it was put on the Tier 2 Watch List. ${ }^{169}$ In addition to the shaming effect that low placements can produce, the possibility of financial sanctions ${ }^{170}$ for non-compliance with what the United States considers minimum requirements ought to be attributed with encouraging foreign States to implement human sex trafficking legislation.

\section{THE TIER SYSTEM: AN EVALUATION OF JAPANESE LAW}

\section{A. Prevention}

The problem for Japan in the U.S. analysis is not generally in the realm of prevention as far as the US State Department is concerned. The government of Japan demonstrated modest efforts to prevent trafficking in persons during the reporting period." ${ }^{171}$ Detected victim counts were up in 2011, going from forty-three detected victims in 2010 to forty-five victims in $2011 .{ }^{172}$

However, there may be more problems with the strict restrictions on the "entertainer" than suspected by the United States. The entertainer visa is identified as the most prevalent method brokers and pimps use to traffic women into Japan "legally." 173 In order to keep potential victims from becoming vulnerable to potential trafficking brokers, opening up legitimate avenues into the country may have merit. "[N]ations must assist each other economically and with employment opportunities. ..." ${ }^{174}$ And the limitation of visas for foreigner leaves women looking to better their financial status at a loss, leaving them vulnerable to predation by exploiters. ${ }^{175}$ Additionally, in the case of individuals such as Filipina hostesses in Japanese clubs, it is a technicality of the system that forces them to be trafficked persons. ${ }^{176}$

Prevention can be better achieved by limiting demand for sex

\footnotetext{
${ }^{168}$ Weiss, supra note 165 , at 327.

${ }^{169}$ Kitamura, supra note 18, at 348-49.

170 Peters, supra note 128, at 7; U.S. State Department, Trafficking in Persons Report 2013, 47, http://www.state.gov/documents/organization/210737.pdf.

171 U.S. Department of State, “Japan”, Trafficking in Persons Report 2013, http://www.state.gov/documents/organization/210740.pdf.

172 United Nations Office on Drugs and Crime, “Japan”, Country Profiles: South Asia, EAST AsIA, AND THE PACIFIC (2012), http://www.unodc.org/documents/data-andanalysis/glotip/Country_Profiles_South_Asia_East_Asia_and_Pacific.pdf.

173 Rhacel Salazar Parrenas, Symposium, Sex for Sale: Trafficked? Filipino Hostesses in Tokyo's Nightlife Industry, 18 YALE J.L. \& FEMINISM 145 (2006).

${ }^{174}$ Wendy M. Gonzalez, Human Trafficking: Criminalization of Victims in the Sex Industry, 11 Buff. Women's L.J. 19, 25 (2002/2003).

175 Parrenas, supra note 173, at 173.

${ }^{176}$ Id. at 168.
} 
trafficking and exploitation rather than by restricting immigration. ${ }^{177}$ However, as will be discussed in a later section, decreasing demand can do only so much, which is why limiting demand should be attempted in conjunction with limiting supply. ${ }^{178}$

\section{B. Prosecution}

Japan's problem in this area of evaluation stems from its poor legal definitions. "Japan's criminal code, as amended in 2004, only prohibits the 'buying and selling of persons,' an overly narrow definition that does not conform to international standards." 179 The narrow definition prevents effective prosecution since the crime of human trafficking is much more specific than the buying and selling of persons, ${ }^{180}$ and thus lumps in other crimes such as immigration violations and human smuggling as human trafficking. "The difference between trafficking and smuggling is frequently unrecognized by law enforcement in Japan. This problem hinders exploited women from receiving help because government authorities are more likely to recognize a trafficked person as victim, while treating a smuggled person as a criminal." 181

Japan's criminal justice system does not utilized prison sentences very often. The prosecution of those charged with trafficking crimes "resulted in convictions of 30 people, though these convictions were obtained using nontrafficking statutes, and so it was unclear if any involved proving elements of human trafficking offenses. Of the 30 convicted defendants, only two served prison sentences; six defendants received fines.”182

Additionally, the Japanese Penal Code is too lenient in regards to sex trafficking. The "articles 226 and 227 of the Penal Code and the Prostitution Prevention Law, prescribe punishments ranging from one to 10 years imprisonment, which are sufficiently stringent and generally commensurate with penalties prescribed for other serious crimes, such as rape." ${ }^{183}$ One year for trafficking in a human being for the purpose using him or her for a sexual purpose is too heinous a crime for a minimum of one year in prison. The low penalty for rape is not the norm in the region. South Korea mandates as

\footnotetext{
177 See infra Section VIII(B)(1).

178 See infra Section VIII(B)(2).

179 U.S. Department of State, “Japan”, Trafficking in Persons Report 2013, http://www.state.gov/documents/organization/210740.pdf.

180 United Nations Protocol to Prevent, Suppress And Punish Trafficking in Persons, ESPECIALLY WOMEN AND CHILDREN, article 3(a), http://www.uncjin.org/

Documents/Conventions/dcatoc/final_documents_2/convention_\%20traff_eng.pdf.

${ }^{181}$ Yun, supra note 55, at 208.

182 U.S. Department of State, “Japan”, Trafficking in Persons Report 2013, http://www.state.gov/documents/organization/210740.pdf

183 U.S. Department of State, “Japan”, TrafFicking in Persons Report 2013, http://www.state.gov/documents/organization/210740.pdf
} 
punishment for rape of an adult female a jail term of at least three years. ${ }^{184}$ If an act of sexual violation results in the death or injury of the victim, then the penalty is enhanced to a prison term of at five years, but can extend to life imprisonment. ${ }^{185}$ Under the criminal code of the People's Republic of China, a person who rapes an adult woman shall be sentenced to at least three years but no more than ten years in prison. ${ }^{186}$

\section{Protection}

Hampered by its overly narrow definition of human trafficking, the government of Japan sustained previous minimal efforts to protect victims during the reporting period . . . Only 27 adult female sex trafficking victims were identified in 2012, a decrease from 45 in 2011. Out of the 27, 11 were Japanese nationals, and the rest were foreign nationals. ${ }^{187}$

In the world, there is an estimated 2.5 million people being trafficked (including sex trafficking), with an estimated 1.4 million of those people are trafficked within Asia and the Pacific. ${ }^{188}$ It is highly unlikely that there were only 27 victims to be identified within Japan's borders.

Additionally, Japan has failed to offer assistance to victims through granting temporary visa status.

While victims were encouraged to participate in the investigation and prosecution of their traffickers, they were not allowed to work during those processes. Because victims cannot work during that period unless they obtain a different visa status, only 27 victims provided limited assistance to police and most chose to repatriate before their trials began. ${ }^{189}$

\footnotetext{
${ }^{184}$ CRIMINAL ACT, article 297 (S. Kor.), last amended in 2005, http://www.acrc.go.kr/ file/file.do?command=downFile\&encodedKey=MTIxXzE\%3D.

185 Criminal Act, article 301 (S. Kor.), last amended in 2005, http://www.acrc.go.kr/ file/file.do?command=downFile\&encodedKey=MTIxXzE\%3D.

186 CRiminal LAW of the PeOple's Republic of China, article 236, available at http://www.asianlii.org/cn/legis/cen/laws/clotproc361/.

187 U.S. Department of State, “Japan”, Trafficking in Persons Report 2013, http://www.state.gov/documents/organization/210740.pdf.

${ }^{188}$ UN.GIFT, “Human Trafficking: The Facts” (2006) http://www.unglobalcompact.org/ docs/issues_doc/labour/Forced_labour/HUMAN_TRAFFICKING_-_THE_FACTS_final.pdf.

189 U.S. Department of State, “Japan”, Trafficking in Persons Report 2013, http://www.state.gov/documents/organization/210740.pdf.
} 
While it is somewhat problematic that victim assistance is offered based upon how useful the victim can be to police, it is even more concerning that victims faced further hardship after police had apprehended the persons who had trafficked and exploited them.

Male victims need protection as well. "Although the 2009 action plan calls for male victim protection policies, Japan has no dedicated shelters or clear sheltering resources for male victims." 190 This Note's primary focus has been on female victimization due to the overwhelming majority of sex trafficking victims being female. However, equal protection of all victims is logically essential to comprehensive victim protection plan. Japan's lack of male or co-ed shelters, and the lack of political will to institute the reform, demonstrate why Japan has fallen short in the area of evaluation.

\section{Why Has Japan Stagnated at Tier 2?}

Japan has stagnated due to a seeming decrease in political will to get things done in combination with taking the wrong approach to eliminating sex trafficking across and within its borders. The U.S. Trafficking in Persons Report remarks:

Despite limited law enforcement gains during the year, the Japanese government did not develop or enact legislation that would fill key gaps in facilitating anti-trafficking prosecutions, as recommended by this Report for the last four consecutive years. The government also failed to develop trafficking-specific assistance measures, continuing instead to rely on inadequate prefectural-level domestic violence shelters. ${ }^{191}$

When compared with the South Korea, a country that seemed to jump through the United States' Tiers without even having a comprehensive sex trafficking law until 2013, Japan's placement on Tier 2 does not appear to make sense. However, there is a glaring difference between South Korea's governmental policy towards human sex trafficking: continual action. South Korea was continually cited by report after report to be making great strides from year to year. ${ }^{192}$ In the most recently published Trafficking in Persons Report, South Korea's efforts were described with certain key phrases such as "took active steps," "sustained strong efforts," and "increased its efforts." 193 Japan, in contrast, had its own efforts described more modestly.

\footnotetext{
${ }^{190} I d$.

${ }^{191} \mathrm{Id}$.

192 Weiss, supra note 165 , at 326-7.

193 U.S. Department OF State, “Korea, Republic of”, Trafficking in Persons Report 2013, http://www.state.gov/documents/organization/210740.pdf.
} 
For example, phrases such as "limited increase" and "modest efforts" made an appearance in comparable locations of the United States' Department of State's evaluation. ${ }^{194}$ Japan has stagnated in the Tier rankings because it has stagnated in government and police action against sex trafficking, and human trafficking in general. ${ }^{195}$ Also, the reform plan concerning human trafficking, with sex trafficking included, has languished in legislative limbo since 2009.

\section{RECOMMENDATIONS}

While some of these recommendations may not be enumerated in or may run contrary to the current criteria supplied by the United States Department of State, these are the best courses of actions based upon available information and literature.

\section{A. Becoming a Party to the Protocol and Forming a Regional Coalition}

While there are problems with the Protocol, and while Japan has put forth some efforts at conforming to Protocol standards, becoming a party to the UN TIP Protocol is a useful step in the right direction for Japan to be taken off the Tier 2 list. Becoming a State Party to the Protocol would formalize Japan's consent to be bound by the treaty's provisions, including those about information sharing and resolution of disputes. ${ }^{196}$ It would create a primary international legal obligation for the Japanese government to fulfill, which has the chance of prompting more concrete actions towards the elimination of sex trafficking. ${ }^{197}$

There is more to combating sex trafficking than preventing vulnerable populations outside of a single country's borders, even if that country is an island nation. Regional trafficking across boarders makes up $45 \%$ of all human trafficking, close to being double the $27 \%$ of victims who are trafficked within their origin country. ${ }^{198}$ Because of this trend, reduction or elimination of human trafficking in all its forms requires cooperation of governments and non-governmental entities. ${ }^{199}$ The United States includes

\footnotetext{
194 U.S. Department of State, “Japan”, Trafficking in Persons Report 2013, available at http://www.state.gov/documents/organization/210740.pdf.

195 See evaluations of Japanese law in previous subsections. See infra Part VII(A)-(C). See also Yun, supra note 55, at 206-10.

196 Vienna Convention ON THE LAW OF TREATies (1969), articles 14 \& 26, http://legal.un.org/ilc/texts/instruments/english/conventions/1_1_1969.pdf.

197 VienNa CONVENTION ON THE LAW OF Treaties (1969), article 26, http://legal.un.org/ilc/texts/instruments/english/conventions/1_1_1969.pdf. ("Every treaty in force is binding upon the parties to it and must be performed by them in good faith.”)

198 United Nations Office on Drugs and CRime, Global Report on Trafficking in PERSONS 1, 13 (2012), http://www.unodc.org/documents/data-and-analysis/glotip/ Trafficking_in_Persons_2012_web.pdf.

${ }^{199}$ Mutlag, et. al, supra note 91.
} 
this factor in its own evaluation of other countries by including it its evaluation criteria: "Whether the government of the country cooperates with other governments in the investigation and prosecution of severe forms of trafficking in persons." 200

It is the position of this Note that Japan should take direct initiative in this respect, as it has already "negotiated memoranda of understanding on trafficking prevention with several Southeast Asian [nations] . . . leading to increased cooperation, including cooperation with Thailand that resulted in the arrest of Japanese and Thai trafficking offenders in Japan.”201 Japan has begun the process in building an anti-trafficking relationship with nearby nations; it only has to extend these efforts further to include other East and Southeast Asian nations.

\section{B. Prevention: Addressing Root Causes of Sex Trafficking}

There are five general categories of structural factors responsible for the increase of sex trafficking across the globe. These five factor categories are economic policies, globalization of the sex industry, male demand, female supply based on women's inequalities, racial myths and stereotypes, and military presence. ${ }^{202}$ The recommendations laid out in this section will focus on 1) demand as influenced by expectations of leniency and sociocultural factors, 2) supply of vulnerable women, and 3) as an extension of constricting supply, reform of Japan's current immigration policy concerning “entertainer” visas.

\section{Decreasing Demand for Forced Sex Labor}

One of the most effective methods to combat an illicit market is to make more efforts to decrease demand. Thus, it should be a priority to reduce demand. ${ }^{203}$ Specifically, Japan should focus on decreasing the demand for women trafficked for the purpose of sexual exploitation, which is not the

\footnotetext{
200 The Victims of Trafficking and Violence Protection Act of 2000, Div. A of Pub. L. No. 106-386, § 108(b)(4), available at http://www.state.gov/j/tip/laws/61124.htm; as amended available at http://www.state.gov/j/tip/rls/tiprpt/2013/210553.htm.

201 U.S. DePartment OF State, “Japan”, TrafFicking in Persons RePORT 2013, http://www.state.gov/documents/organization/210740.pdf

${ }^{202}$ Gonzalez, supra 174, at 20; Also, “[s]upply factors include regional conflicts, oppression by families, lack of economic and educational opportunity, responsibility for care of family members, and other problems women face in developing countries. These factors create the 'feminization of immigration' in which women are more likely to travel abroad in search of opportunities and become more likely to be exploited.” Yun, supra note 55, at 250.

${ }^{203}$ Yen, supra note 4.
} 
same as decreasing demand for prostitution. ${ }^{204}$ However, other than the criminalization of un-coerced commercial sex acts, efforts to reduce demand for sex-trafficked individuals should follow similar models to those which advocate for the abolition of prostitution. ${ }^{205}$ For Japan there are two primary ways to do so: general deterrence (which could also fall under the "P" of Prosecution), and educational and social reforms.

"Laws geared towards demand reduction should include increased fines and jail time for those who purchase sex [from trafficked individuals], and licensing forfeitures and civil penalties for employers complicit in the use of trafficked employees.”206 Japan must increase penalties for human trafficking, particularly for sexual exploitation, and make more efforts to look past stereotypes in order to identify victims. One year for the crime of trafficking is astonishingly lenient. This should be increased to a minimum sentence of five years and a maximum of fifteen years. If this recommendation is considered too high, then the East Asian regional norm of a minimum of three years in prison described above ${ }^{207}$ will be sufficient so as to at least comport with regional punitive norms. In order to make these increased penalties more effective, Japanese courts must alter their sentencing practices to ensure that sex traffickers spend time in prison.

In order to aid in prosecution efforts, Japan must increase victim services and awareness about victim services will allow problem businesses or individuals to be reported. After all, "[t]here can be no criminal prosecution if a victim does not feel safe and secure enough to testify."208

In addition to increased penalties for those who participate in the trafficking of individuals for the purpose of sexual exploitation, Japan must focus on domestic educational programs for its citizens. Awareness programs to tackle underlying socio-cultural factors such as sexism and racism are necessary, despite the lack of specific enumeration in the Victims of Trafficking and Violence Protection Act. ${ }^{209}$ "[W]omen continued to be

\footnotetext{
204 See generally Global Alliance Against Traffic in Women, Moving Beyond 'Supply and Demand' Catchphrases: Assessing the Uses and Limitations of Demand-Based Approaches in Anti-Trafficking (2011), available at http://www.gaatw.org/publications/ MovingBeyond_SupplyandDemand_GAATW2011.pdf.

205 Additionally, since Japan already criminalized acts of prostitution and purchasing sex from a prostitute, it will presumably be more efficient for the time being for Japan to work within the so-called abolitionist demand elimination framework.

${ }^{206}$ Mutlag, et. al, supra note 91.

207 See infra Part VII(B).

${ }^{208}$ Mutlag, et. al, supra note 91.

209 The Act only mentions “... . measures to inform and educate the public, including potential victims, about the causes and consequences of severe forms of trafficking in persons...” THE Victims of Trafficking and Violence Protection Act of 2000, Div. A of Pub. L. No. 106386, § 108(b)(3), available at http://www.state.gov/j/tip/laws/61124.htm; as amended available at http://www.state.gov/j/tip/rls/tiprpt/2013/210553.htm.
} 
marginalized socially, culturally, economically and politically in Japan.”210 Additionally, there is a stark difference in Japanese culture between someone who is Japanese and someone who is not Japanese. ${ }^{211}$ Even those Japanese citizens who are descendents of other ethnicities such as Taiwanese or Korean are socially discriminated against by ethnic Japanese. ${ }^{212}$ This gap between Japanese and "other" heavily contributes to exploitation of immigrants. ${ }^{213}$ In combination with the inequality afforded in action to women in general, this practice of discrimination leaves female immigrants to be viewed as inferior, further contributing to their vulnerability.

Combating such socio-cultural stereotypes should take the form of mass public educational programs. The Japanese media can be instrumental in implementing this approach by challenging misconceptions of gender, sex, and immigrants. ${ }^{214}$ The Japanese media can work in conjunction in media in other nations (perhaps in the theoretical regional coalition) in order to disseminate information about Japan to potential victims as well.

\section{Decreasing the "Supply Stream"}

Victims of sex trafficking may be referred to as the "supply" part of the supply and demand functioning of the trafficking industry. ${ }^{215}$ Restricting supply does not necessarily involve immigration policies. Victims are often from vulnerable populations with any number of factors increasing susceptibility to trafficking. ${ }^{216}$ These factors include "widespread poverty, poor education or educational opportunities, diminished economic prospects and insufficient aid from state infrastructure." ${ }^{217}$ It has been suggested that, instead of demand shaping supply in the case of sex trafficking, supply shapes demand. ${ }^{218}$ Thus, by changing or constricting the supply of women vulnerable to sexual exploitation, it is possible to create a smaller demand market.

Constricting the supply of victims is also referred to as "victimfocused" prevention. ${ }^{219}$ By aggressively addressing the procurement of

\footnotetext{
${ }^{210}$ Yun, supra note 55, at 210.

${ }^{211} \mathrm{Id}$. at 213.

212 Id.

${ }^{213} I d$.

${ }^{214}$ Id. at 253.

${ }^{215}$ Kalen Fredette, Revisiting the U.N. Protocol on Human Trafficking: Striking Balances for More Effective Legislation, 17 CARDOZO J. INT'L \& COMP. L. 101, 105 (2009).

${ }^{216} I d$.

${ }^{217} \mathrm{Id}$.

218 See also Global Alliance Against Traffic in Women, Moving Beyond 'Supply and Demand' Catchphrases: Assessing the Uses and Limitations of Demand-Based Approaches in Anti-Trafficking 21 (2011), available at http://www.gaatw.org/publications/ MovingBeyond_SupplyandDemand_GAATW2011.pdf.

${ }^{219}$ Fredette, supra note 215, at 127.
} 
victims, recruitment will become incredibly limited. ${ }^{220}$ A regional coalition, which Japan ought to initiate, would contribute greatly to the facilitation of programs which could lessen the vulnerability of potential victims (such as education and more legitimate employment). This approach would allow Japan to coordinate its efforts with potential source countries for sex trafficking victims in order to ensure that appropriate and comprehensive programs are instituted. Additionally, Japan should work closely with NonGovernment Organizations (NGOs) in order to implement potential victimoriented educational and work programs.

\section{Modification Japanese Immigration Law and Domestic Assistance for Victims}

In general, restrictive immigration policies limit access for foreigners to legitimate domestic employment opportunities, contributing to sex trafficking industry. ${ }^{221}$ Specifically in Japan, the law regarding the certification of those who apply for "entertainer" visas creates vulnerability of potential victims. The current system creates a middle-man broker system which leaves women vulnerable to sexual exploitation in the form of indentured servitude. ${ }^{222}$ Expansion of qualifications for work visas will increase potential victims' opportunities to find legitimate jobs, not make them more vulnerable to traffickers.

Additionally, in regards to protecting the rights of those who have already fallen victim to sex trafficking, Japan ought to institute a system of providing visas to identified victims so that the victims can assist in the prosecution of their traffickers and abusers. ${ }^{223}$ These visas should include "a path to citizenship for the victim, working permits for the victims, and allowance for the victim to bring family members into the country."224

\section{CONCLUSION}

Japan's history with human sex trafficking is a long one. Since feudal times, Japan has been attempting to regulate practice of sexual exploitation. However, the real boom in activity came in the modern era, as globalization and easy methods of transnational travel swept the globe. The worldwide reaction was to regulate and to attempt to create a comprehensive law enforcement approach to eliminating sex trafficking (and all other forms of human trafficking), producing the United Nations Trafficking in Persons

\footnotetext{
${ }^{220} I d$.

${ }^{221}$ Gonzalez, supra 174, at 20-1.

222 Parrenas, supra note 173, at 168.

${ }^{223}$ Mutlag, et. al, supra note 91.

${ }^{224}$ Id.; See e.g., The Violence Against Women Act (2013), Title VIII (which provides for the obtaining of a special U-visa for women who are victims of human trafficking).
} 
Protocol of 2000. The United States followed up the United Nations with its own version of a law enforcement focused approach. In some ways, there were advantages to the U.S. plan of action which included not only prosecution of individual traffickers for a variety of criminal offenses, but also an evaluation system that combined with financial aid incentive to entice foreign nations to bring their own anti-trafficking laws up to snuff. Unfortunately, this general approach has flaws and those flaws are made apparent in Japan's anti-trafficking efforts.

Therefore, in order for Japan to make it off the Tier 2 List, it must, first and foremost, exercise its political will. Clamping down on immigration does not stop sex trafficking. It merely causes traffickers to get more creative or more manipulative of vulnerable women. However, getting off the Tier 2 List is not the end-all-be-all where Japan's anti-trafficking efforts are concerned. Japan must show that it takes such crime seriously by increasing penalties and facilitating detection of victims through a regional coalition of Asian states. Japan has already made treaties and agreements with a few of its neighbors, and is currently the best ranked in the region. It makes Japan an ideal candidate for spearheading a regional effort to combat trafficking

Inside Japan's borders, there must be more money and time spent on facilitating comprehensive public awareness and education of Japanese supply and demand populations. That is, Japan must seek to address stillpresent plagues of sexism and racism that combine to make foreign female immigrants to Japan particularly vulnerable to trafficking for the purpose of exploitation. This does not mean, however, that Japan should continue to tighten its immigration policies. Instead, Japan should seek to expand opportunities for foreign female individuals for study and employment, and relax its immigration policies in regard to "entertainer" visas. There are also a variety of victim services that ought to be expanded. These are but a few recommendations that would serve to not only generally improve Japan's anti-sex trafficking approach, but also would lift Japan up to the first Tier. 